\title{
PENGARUH KONFLIK PERAN DAN LINGKUNGAN KERJA TERHADAP KINERJA KARYAWAN WANITA PADA PT. BANK BRI CABANG PALOPO
}

\author{
ALTRI WAHIDA*1 \\ 1Universitas Muhammadiyah Palopo \\ *altri.wahida@yahoo.com
}

\begin{abstract}
Absract
This research was conducted at the BRI Bank in Palopo Branch, and the research period was approximately one month. The analytical method used in this study is a quantitative method, using multiple regression analysis tools, which are processed by the SPSS Ver program. 16. The results of the analysis show that the Role Conflict, Work Load and Work Environment has a significant effect on the Performance of Female Employees at PT. BRI Bank Palopo Branch. This is indicated by the regression coefficient value.
\end{abstract}

Keywords: Role Conflict, Work Environment, Female Employee Performance

\begin{abstract}
Abstrak
Penelitian ini dilakukan di Bank BRI Cabang Palopo, dan waktu penelitian dilakukan kurang lebih satu bulan. Adapun metode analisis yang digunakan dalam penelitian ini adalah metode kuantitatif, dengan menggunakan alat analisis regresi berganda, yang pengolahannya di bantu program SPSS Ver. 16. Hasil analisis menunjukkan bahwa Konflik Peran, Beban Kerja dan Lingkungan Kerja berpengaruh signifikan Terhadap Kinerja Karyawan Wanita Pada PT. Bank BRI Cabang Palopo. Hal ini ditunjukkan dengan nilai koefisien regresi.
\end{abstract}

Kata kunci : Konflik Peran, Lingkungan Kerja, Kinerja Karyawan Wanita.

\section{PENDAHULUAN}

Dilihat dari pertumbuhan bisnis perbankan di Indonesia dinilai cukup pesat. Ada sekitar 123 bank di Indonesia, belum termasuk bank rakyat yang terdapat di daerah-daerah. Apabila kita melihat karir expo di tahun 2010-2011 yang sering diadakan di berbagai wilayah di Indonesia, bidang perbankan dan keuangan adalah salah satu bidang favorit yang diincar para pencari kerja. Buktinya adalah jumlah antrian dan lamaran yang menumpuk di stand milik bank-bank swasta, perusahaan pembiayaan sampai perusahaan asuransi.

Terkadang karyawan merasa bingung akan posisi apa yang cocok untuknya, terutama karyawan wanita sehingga dapat mengurangi kinerja kerja dalam sehariharinya tanpa meninggalkan pekerjaannya sebagai ibu rumah tangga. Oleh karena itu, posisi-posisi yang ada di bank beserta bidang yang dilingkupinya: Pelayanan (call centre, teller, and costumer service), Marketing (bagian Funding dan Lending), Operasi (Processing, Settlement, dan Kliring), Support (bagian Administrasi, Legal, dan Credit Analyst), non-operasional (Human Resource Department, IT, compliance, risk management and produk).

Menurut Mudayana (2010), banyaknya tugas dan tanggung jawab yang diberikan kepada karyawan menyebabkan hasil yang dicapai menjadi kurang maksimal karena karyawan hanya mempunyai waktu yang sedikit untuk menyelesaikan banyak tugas. Perlu dilakukan upaya untuk memotivasi karyawan agar mampu melaksanakan 
tugasnya dengan baik sesuai job description yang sudah ditetapkan.

Dalam bekerja, terutama bagi karyawan wanita diharapkan lebih bijak untuk menjaga kestabilan pikiran dan perasaan mereka, karena selain diharapkan performa yang baik, karyawan juga dapat mengelolah rumah tangga dengan baik. Kondisi seperti ini disebut konflik peran, dimana konflik peran ini mengakomodasikan dua aspek yang cukup berimbang. Satu sisi dituntut untuk performa kerja yang optimal, disisi lain bagi karyawan wanita juga dituntut oleh keluarga sebagai ibu rumah tangga.

Menurut Duxburry dan Higgins (2003), dampak dari konflik peran yang dialami oleh para wanita yang bekerja, berdampak tidak hanya terhadap dirinya sendiri, namun juga terhadap keluarga dan perusahaan atau instansi tempat ia bekerja. Dalam perusahaan atau instansi tempat ia bekerja akan dapat menurunkan kepuasan kerja, meningkatnya tingkat stres kerja, meningkatnya beban kerja, jumlah jam kerja dan juga akan dapat meningkatkan tingkat absensi pada para karyawan yang terkait

Konflik peran dapat terjadi pada karyawan wanita PT. Bank BRI Cabang Palopo jika semakin banyak waktu yang digunakan untuk bekerja, dan semakin sedikit waktu untuk keluarga, sehingga memiliki beban kerja yang tidak kondusif dan dapat menimbulkan stress kerja maupun kondisi kesehatan.

\section{Konflik Peran}

Konflik peran merupakan adanya ketidakcocokan antara harapan-harapan yang berkaitan dengan suatu peran dimana dalam kondisi yang cukup ekstrim, kehadiran dua atau lebih harapan atau tekanan akan sangat bertolak belakang sehingga peran yang lain tidak dapat dijalankan. Penelitian yang dilakukan oleh Duxburry dan Higgins (2003),
Selayaknya dalam bekerja sehari-harinya, karyawan harus lembur jika pekerjaan yang diberikan belum selesai, pada akhir bulan, triwulan, semesteran dan tahunan, dimana mereka diharuskan membuat laporan kinerja. Selain itu, terkadang harus bekerja pada hari libur, yaitu hari Sabtu dan Minggu dan juga hari raya lainnya, sehingga peran wanita sebagai ibu rumah tangga tidak berjalan sebagai mana semestinya.

Berdasarkan penelitian sebelumnya mengenai variabel konflik peran dan variabel lain, terhadap kinerja karyawan wanita, ternyata ada banyak yang menyebabkan terjadinya konflik peran ganda yang dialami karyawan wanita ini, diantaranya adalah kurang atau bahkan tidak adanya waktu untuk keluarga, tidak adanya waktu untuk bermasyarakat, penggunaan hari libur untuk bekerja, permasalahan dalam keluarga, dan keluhan dari anggota keluarga atas pekerjaan yang dijalani karyawan wanita. Agar konflik peran ganda ini tidak mempengaruhi kinerja karyawan, pemberian beasiswa bagi anak karyawan yang berprestasi, memberlakukan sistem kerja shift, sehingga karyawan wanita tersebut memiliki waktu untuk keluarga dan bermasyarakat, hari raya sebaiknya karyawan wanita tetap libur, sehingga karyawan wanita tersebut dapat menikmati liburan bersama keluarga dan juga mengurangi rasa lelah setelah seminggu bekerja.

\section{TINJAUAN PUSTAKA}

sejalan dengan pernyataan sebelumnya, namun ia menambahkan dampak yang ditimbulkan dari konflik peran yaitu partisipasi seseorang pada satu peran menyulitkan partisipasi pada peran yang lainnya.

Dampak dari konflik peran Konflik peran yang dialami oleh para wanita yang bekerja berdampak tidak hanya terhadap 
dirinya sendiri, namun juga terhadap keluarga dan perusahaan atau instansi tempat ia bekerja. Dalam perusahaan atau instansi tempat ia bekerja akan dapat menurunkan kepuasan kerja, meningkatnya tingkat stres kerja, meningkatnya beban kerja dan jumlah jam kerja, dan juga akan dapat meningkatkan tingkat absensi pada para karyawan yang terkait (Duxburry dan Higgins, 2003).

Konflik bisa jadi merupakan sumber energi dan kreativitas yang positif apabila

\section{Kinerja Karyawan Wanita}

Pengertian kinerja menurut Benardin dan Russell dalam penemuan Winanti (Majalah Ilmiah UNIKOM, 2011), kinerja adalah pencatatan outcome yang dihasilkan pada fungsi atau aktivitas pekerjaan secara khusus selama periode waktu tertentu. Robbins dalam penemuan Pramudyo (JBTI, 2010:4), menyatakan bahwa kinerja adalah ukuran mengenai apa yang dikerjakan dan apa yang tidak dikerjakan oleh karyawan. Kinerja dosen merupakan salah satu faktor penentu

\section{METODE PENELITIAN}

Penelitian ini yang dijadikan populasi adalah seluruh karyawan wanita yang sudah menikah yang ada pada PT. Bank BRI Cabang Palopo. Salah satu teknik Probbability Sampling yang digunakan metode Sampling Jenuh. Sampling Jenuh adalah metode penentuan sampel bila dalam penelitian ini adalah Kuesioner yaitu data yang dikumpulkan berupa persepsi responden terhadap variabel penelitian. Studi berupa data base karyawan

\section{HASIL PENELITIAN DAN PEMBAHASAN}

Setelah melakukan pengujian mengenai pengaruh konflik peran (X) terhadap kinerja dikelola dengan baik. Misalnya, konflik dapat menggerakkan suatu perubahan : Membantu setiap orang untuk saling memahami tentang perbedaan pekerjaan dan tanggung jawab mereka, memberikan saluran baru untuk komunikasi, menumbuhkan semangat baru pada staf, memberikan kesempatan untuk menyalurkan emosi, menghasilkan distribusi sumber tenaga yang lebih merata dalam organisasi.

keberhasilan proses belajar mengajar di perguruan tinggi.

Sikap mental merupakan kondisi mental yang mendorong diri pegawai untuk berusaha mencapai prestasikerja secara maksimal. Sikap mental seorang pegawai harus sikap mental yang siap secara psikofisik (sikap secara mental, fisik, tujuan dan situasi). Artinya seorang pegawai harus siap mental, mampu secara fisik, memahami tujuan utama dan target kerja yang akan dicapai serta mampu memanfaatkan dan menciptakan situasi kerja.

anggota populasi relatif kecil. Berdasarkan data dari PT. Bank BRI Cabang Palopo maka jumlah sampel sebesar 30 karyawan. Teknik yang digunakan dalam memperoleh data yang dibutuhkan

literatur yaitu mengumpulan data-data sekunder

karyawan wanita (Y) maka akan dibahas sebagai berikut: 
Hal. 1-5

Dari hasil analisis menunjukkan bahwa ratarata responden menyatakan ada pengaruh konflik peran terhadap kinerja karyawan wanita pada PT. Bank BRI cabang Palopo, karena dengan adanya konflik peran, seorang karyawan memiliki kemampuan untuk membagi antara pekerjaan rumah dan kantor agar supaya dapat menyelesaikan tugas tepat waktunya serta pekerjaan yang diberikan sesuia dengan minat dan kemampuannya.

Faktor-faktor yang mempengaruh konflik peran terhadap kinerja karyawan wanita pada PT. Bank BRI cabang Palopo yaitu, Dari hasil analisis menunjukkan bahwa rata-rata responden menyatakan pertama kali seseorang termotivasi bekerja karena adanya kepuasan kerja, dimana dalam perusahaan, kebutuhan ini akan terpenuhi manakalah karyawan wanita tidak bingung dalam membatasi tugas antara keluarga dan kantor. Kebutuhan keamanan dimana kebutuhan ini sangat mempengaruh kinerja karyawan wanita pada PT. Bank BRI cabang palopo berupa kebutuhan keamanan dari rasa depresi, perasaan stress, malu, iri, agresi,

\section{KESIMPULAN}

Berdasarkan hasil analisis dan pembahasan pada bagian sebelumnya, maka dapat diambil kesimpulan yaitu Konflik peran berpengaruh positif terhadap kinerja karyawan wanita pada PT. Bank BRI Cabang Palopo dengan demikian variabel konflik peran dapat dijadikan sebagai variabel kebijakan dalam mendorong peningkatan kinerja karyawan wanita.

\section{DAFTAR PUSTAKA}

Analisa, L. W., \& RAHARDJO, M. (2011). Analisis pengaruh motivasi kerja dan lingkungan kerja terhadap kinerja karyawan (Studi pada dinas perindustrian dan perdagangan kota
pISSN 2088-7485

penggunaan hari libur untuk bekerja, terjadinya keluhan dari anggota keluarga akibat pekerjaan, sering merasa lelah setelah pulang kerja. Semakin banyak waktu yang digunakan bekerja maka semakin sedikit waktu untuk keluarga dan banyaknya anggota keluarga.

Lingkungan Kerja merupakan salah satu faktor penting dalam menciptakan kinerja karyawan. karena Lingkungan kerja mempunyai pengaruh langsung terhadap karyawan didalam menyelesaikan pekerjaan yang pada akhirnya akan meningkatkan kinerja oragnisasi. Suatu kondisi lingkungan kerja dikatakan baik apabila karyawan dapat melaksanakan kegiatan secara optimal, sehat, aman dan nyaman.

Dari hasil analisis menunjukkan bahwa ratarata responden menyatakan bahwa lingkungan kerja berpengaruh terhadap kinerja karyawan. Semakin nyaman lingkungan kerja maka karyawan akan makin semangat untuk meningkatkan kinerja karyawan khususnya karyawan wanita.

Berdasarkan hasil analisis dan pembahasan lingkungan kerja maka dapat diambil kesimpulan yaitu Lingkungan kerja berpengaruh positif terhadap kinerja karyawan pada PT. Bank BRI Cabang Palopo dengan demikian variabel lingkungan kerja dapat dijadikan sebagai variabel kebijakan dalam mendorong peningkatan kinerja karyawan wanita.

\section{Semarang) (Doctoral dissertation, Universitas Diponegoro).}

Arianto, D. A. N. (2013). Pengaruh kedisiplinan, lingkungan kerja dan budaya kerja terhadap kinerja tenaga pengajar. Jurnal Economia, 9(2), 191-200. 
Dhermawan, A. A. N. B., Sudibya, I. G. A., \& Utama, I. W. M. (2012). Pengaruh motivasi, lingkungan kerja, kompetensi, dan kompensasi terhadap kepuasan kerja dan kinerja pegawai di lingkungan kantor Dinas Pekerjaan Umum Provinsi Bali. Matrik: Jurnal Manajemen, Strategi Bisnis dan Kewirausahaan.

KERJA, STRES KERJA, TEKNOLOGI INFORMASI, DAN KINERJA KARYAWAN. Jurnal Ilmiah Manajemen \& Bisnis, 2(2), 298-310.

Konflik, M. (2011). Analisis Pengaruh Manajemen Konflik dan Stres Kerja terhadap Kinerja Karyawan pada PT. General Adjuster Indonesia.

Meidah, E. (2013). Pengaruh Konflik Peran Ganda, Kecerdasan Emosional dan Komitmen Organisasi terhadap Kinerja Perawat Wanita (Studi Kasus Pada Rumah Sakit Islam Jakarta Pondok Ko.

Pinatih, I. G. B. A., \& Gorda, A. A. N. E. S. (2019). GAYA KEPEMIMPINAN, BEBAN

Sidanti, H. (2015). pengaruh lingkungan kerja, disiplin kerja dan motivasi Kerja terhadap kinerja pegawai negeri sipil di Sekretariat DPRD kabupaten madiun. Jurnal Jibeka, 9(1), 44-53.
Sorongan, M. V., Mandey, S., \& Lumanauw, B. (2015). Konflik peran dan ambiguitas peran terhadap kinerja karyawan pada pt. Bank tabungan pensiunan nasional (btpn) tbk. Cabang manado. Jurnal EMBA: Jurnal Riset Ekonomi, Manajemen, Bisnis dan Akuntansi, 3(1).

Wirakristama, R. C., \& SUHARNOMO, S. (2011). Analisis pengaruh konflik peran ganda (work family conflict) terhadap kinerja karyawan wanita pada PT Nyonya Meneer Semarang dengan stres kerja sebagai variabel intervening (Doctoral dissertation, Universitas Diponegoro).

Widyaningrum, I. A., Pongtuluran, Y., \& Tricahyadinata, I. (2013). Pengaruh konflik peran ganda dan stres kerja terhadap kinerja karyawan wanita pada Swalayan Era Mart 5000 di Samarinda. Samarinda: Universitas Mulawarman.

Talkshow oleh Michael R. Tampi, Secured Loan Manager Metropolitan Jabodetabek bank OCBC NISP. (http://female.kompas.com/read/201 0/10/16/16302384/Kerja.di.Bank..Un tung.Besar..Stres.Level.Tinggi.). Diakses 26-6-2015. 